\title{
A study on extent of involvement of rural women in agro based enterprises
}

\author{
RULIMA BHARALI* AND MANJU DUTTA DAS \\ Department of Extension and Communication Management, Faculty of Home Science, \\ Assam Agricultural University, JORHAT (ASSAM) INDIA
}

\begin{abstract}
The present study was conducted with 240 rural women who were engaged in both vegetable cultivation and livestock in 24 villages of three agro climatic zones of Assam, to know the extent of involvement of rural women in vegetable cultivation and livestock rearing. Data were collected personally by interview method. The findings revealed that majority of rural women had high involvement in vegetable cultivation and livestock rearing followed by medium and low involvement. The result of the study showed that the involvement of rural women in vegetable cultivation was significantly and positively related with marital status but not with age, caste, education, land holding, family occupation, family type, family size, organizational membership, socio economic status and mass media exposure. The findings revealed that the involvement of rural women in rearing of livestock was significantly and positively related with family occupation, family type and family size whereas there is no significant relationship between involvement of rural women in rearing of livestock and age, caste, education, land holding, organizational membership, socio-economic status and mass media exposure.
\end{abstract}

KEY WorDS : Involvement; Rural women, Agro-based enterprises, Vegetable cultivation, Livestock rearing

View Point Article : Bharali, Rulima and Das, Manju Dutta (2016). A study on extent of involvement of rural women in agro based enterprises. Internat. J. Home Sci. Extn. \& Comm. Manage., 3 (2) : 72-77. DOI : 10.15740/HAS/IJHSECM/3.2/ 72-77.

Article History : Received : 02.06.2016; Revised : 13.06.2016; Accepted : 28.06.2016

\footnotetext{
* Author for correspondence (Email : rulimabharali@gmail.com)
} 